\title{
THE IMPLEMENTATION CLT APPROACH TO IMPROVE STUDENTS SPEAKING SKILLS
}

\author{
Ayu Octavianita ${ }^{*}$ \\ Kiki Wahyuni \\ Suryadi Amdhan Nur ${ }^{3}$ \\ Tuti Handayani ${ }^{4}$ \\ Muhammad Taufik Ihsan ${ }^{5}$ \\ 1,2,3,4,5 Departement of English Education, Faculty of Education and Teacher Training \\ State Islamic University of Sultan Syarif Kasim Riau, Indonesia \\ 11910420406@students.uin-suska.ac.id $\left.{ }^{1 *}\right)$ \\ 11910421264@sudents.uin-suska.ac.id $\left.{ }^{2}\right)$ \\ 11910413107@students.uin-suska.ac.id ${ }^{3}$ ) \\ 11910420525@students.uin-suska.ac.id $\left.{ }^{4}\right)$ \\ muhammad.taufik.ihsan@uin-suska.ac.id ${ }^{5)}$
}

\begin{abstract}
The goal of this study is to find out how instructors employ the Communicative Language Teaching approach in the English classroom, as well as the strategies and resources they use to help students develop their speaking skills. This can be seen from the class activities, speaking materials until the strategies that has been implemented in some research. This article takes the form of a review of documents and literatures, with an evaluation of knowledge as the basis. As a result, as a teacher, you may learn from other countries that have successfully implemented and developed CLT in improving students' speaking skills.
\end{abstract}

Keywords: Communicative Language Teaching (CLT), Speaking skills, Classroom activities, Strategies.

Published by:

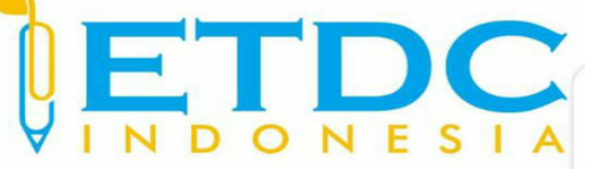

Copyright (C) 2021 The Author (s)

This article is licensed under CC BY 4.0 License

\section{(cc) $\mathrm{BY}$}




\section{THE IMPLEMENTATION CLT APPROACH TO IMPROVE STUDENTS SPEAKING SKILLS}

\section{Introduction}

English is a widely used language on a global scale. People from different nations all over the world utilize it to communicate with one another stated by (Amin, 2004:1). English is essential because it is a language of communication in almost every part of life, including social interaction, science and technology, politics, economics, culture, and education.

Reading, listening, writing, and speaking are the four language skills in English. Harmer (1991:16) argues that, reading and listening are receptive skills, whereas speaking and writing are productive abilities. The final learning objectives are always focused on these abilities. In other words, the four language skills are the end product of a significant learning process; they are the implementation of the language information that learners acquire during that duration.

According to Amin (2004) speaking practice is important for achieving a successful speaking performance, especially when it comes to public speaking and the level of precision that the pupils are attempting to achieve. In reality, when students meet and utilize a foreign language, they are limited in their time to do so individually, topic-by-theme, resulting in a complicated learning situation. To put it another way, students must learn who they are speaking to, where they are speaking from, and what they are speaking about in order to provide a practical speech stated by (Green and Hilton, 1984:40).

Speaking has been noted as a difficult skill to master, despite its importance in human life. People can communicate with one another via speaking. Its success is assessed in terms of its capacity to have a conversation in an interactive process of meaning construction that includes creating, receiving, and processing data. But, someone generally has difficulties in social interaction, such as being unable to communicate his or her views, arguments, or feelings. When someone understands what others are saying but is unable to convey it. This might be due to a lack of practice, motivation, communicative skill, and self-confidence. In an ideal world, anybody who can comprehend an expression should also be able to produce it.

In order to solve these issues, Richards and Rodgers (2001, p. 158) states that the Communicative Language Teaching (CLT) methodology be used to assist students enhance their speaking abilities. Furthermore, CLT allows students to participate actively in activities since it is frequently accompanied by visuals or imagined events, making it more realistic. Students become the major characters in such events, and as a result, they can develop a natural interest in the English language and study it for enjoyment. Furthermore, according to Canale 
and Swain (1980, p. 56), CLT can increase communicative competence, which encompasses grammatical, sociolinguistic, discourse, and strategic competence. In this occasion, the aim of the study is to using CLT approach to improve students speaking skills.

\section{Methodology}

This research is based on a literature review (Research Library) that mostly focuses on journals and other publications to generate the arguments in this article. The first is about communicative language teaching, which will be discussed in a journal and in a few articles. All articles regarding CLT may be found on the internet. In addition, a review of classroom exercises and speaking material is conducted. Articles and online news provide access to all important linked materials. Furthermore, document studies are used to assess the strategies in CLT. In order to have a better understanding of the issues, the author also examines relevant documents.

\section{Discussion}

\section{a. Communicative Language Teaching (CLT)}

First of all, we have to understand the maning of CLT itself. CLT is based on the sociocognitive perspective of sociocultural linguistic theory, which shows itself in the idea of'communicative competence,' according to Hymes (1972). In contrast to Chomsky's "linguistic competence," Hymes invented this concept. According to Chomsky (1968), there is an abstract rule system or knowledge underpinning concrete language performance, and this underlying understanding of the grammar of the language by the native speaker is his "linguistic competence."

It is common knowledge that everyone needs to comprehend spoken language in a variety of contexts, including everyday life, job, school, and community. According to Moss and Ross-Feldman (2003), communication is any action that needs the learner to talk and listen to others. Breaking through boundaries, obtaining information, expressing oneself, and learning about culture may all be aided by communicative activities.

According to Jeyasala (2014), teacher should constantly support students' communicative competence, and they should give them with opportunities to connect with people or immerse them in speaking activities that will improve their capacity to utilize the target language.

This is the best choice for instructors is to provide students with real communicative contexts, so students may share real knowledge and language and phrases will develop as 
needed. Students must also be exposed to the language extensively; the linguistic input they get should give them with opportunities to generate and utilize the language in a variety of situations; motivation is therefore crucial in motivating students to communicate vocally.

Richard (2005) argues that learning a language does not automatically imply that the student will be able to use it fluently. As a result, a lack of fluency can be caused by rigorous formal language acquisition instruction; another explanation could be a lack of techniques to engage students in communicative activities.

According to the author, communicative competence encompasses the following aspects of language knowledge: knowing how to use the language in various situations, knowing how to vary the use of the language according to settings and participants (formal and informal speech), being able to understand various types of texts, and so on.

When utilizing communicative activities in the classroom, a difference should be made between fluency and accuracy, with fluency being defined as the natural language usage that occurs when speakers participate in a discussion despite their communicative competence limitations. On the other hand, accuracy refers to the development of accurate examples of language usage.

\section{b. Classroom Activities of Communicative Language Teaching}

Richards (2006) suggested two process-based approaches for achieving the objective of communicative language teaching: Content-based instruction (CBI) and Task-based instruction (TBI). CBI is an approach that promotes language learning via the use of content, as well as the linking and development of various language abilities. While in TBI, pedagogical and realworld tasks are employed to provide learners the opportunity to participate in meaningful work. The former are tasks that need interaction among learners but are not found in the actual world, whereas the latter are tasks based on authentic materials such as listening exercises, problem solving, sharing personal experiences, and comparing, among other real-life scenarios.

According to Richards and Rodgers (2014) there is more material on Communicative language teaching than there is about learning theory. As a result, they feel it is important to explore the three aspects of learning theory that may be identified in various communicative language teaching approaches. The first part is the communication principle, which refers to acts that stress true communication. On the other side, the task principle emphasizes the use of language to carry out meaningful actions. The idea of meaningfulness, on the other hand, argues that the language used should be meaningful to the learner.

There are several activities that seek to improve learners' communication competence by utilizing communicative processes including information exchange, meaning negotiation, 
and interaction. Similarly, to assist classrooms that employ the Communicative language education approach, games, role plays, simulations, and task-based communication activities are required (Richards and Rodgers, 2014). Similarly, Colker (2007) says that children learn better when they use their senses to look, hear, touch, move, investigate, smell, and even taste things. She feels that having direct touch with the materials helps students learn more effectively.

Furthermore, Abe (2013) says that in schools when the CLT technique is used, group activities and individual growth, debates, and presentations are beneficial. Furthermore, the author claims that students' speaking skills develop as a result of their frequent usage of English, despite the fact that it may be unpleasant for them. As a result, it's critical to develop effective strategies to modify English instruction through group work activities.

\section{c. Speaking Materials of Communicative Language Teaching}

Interaction is crucial in language learning because it allows students to practice their communication abilities. The right resources that encourage meaningful contact among learners must be chosen in order to produce meaningful interaction among learners. According to Richards (2001) materials are the most important aspect of language acquisition, whether they be textbooks, materials given by an institution, or materials created by the teacher. All of these tools are intended to provide students with a foundation for the language practice that will get in the classroom.

Schiffrin (1996) emphasizes the necessity of utilizing suitable material, stating that conventional books frequently contain insufficient target language content and fail to provide students with sufficient communicative input (as cited in Peacock,1997). Furthermore, the authors mention that adding real resources, such as audio-visual content, would provide learners with a deeper contribution that can be used in a variety of methods and levels to develop their communication abilities.

According to Swaffar and Vlatten (1997), employing video in the classroom exposes students to real voices and accents, providing them with cultural context (as cited in Salaberry, 2001). Furthermore, Bahrani and Shu Sim (2011) argue that the usage of television and visual media is not only a form of entertainment but also a form of educational technology. Furthermore, the same author adds that learners would be able to understand the structures utilized in a simple and straightforward manner by watching news broadcasts.

News writers employ terminology that is readily comprehended by the audience in order to capture their attention. According to Yükselir and Kömür (2017), using internet videos in the English classroom helps students to communicate and engage in an appropriate manner, 
allowing them to acquire the ability to easily transfer messages. Furthermore, according to Peacock (1997), a large number of academics feel that using real materials in foreign language classrooms stimulates students. They also feel that authentic materials are more naturally engaging and inspiring than non-authentic things.

\section{d. Strategies in Communicative Language Teaching}

Several research have been conducted over time with the goal of increasing speaking skills, which is currently a serious problem.

Nunan (1987) conducted a study with the goal of determining the extent to which true communication features were visible in communicative language classes and whether techniques might be created to enhance such communication. Five communicative language courses were videotaped, transcribed, and evaluated with this goal in mind. In these classes, communicative language exercises were employed. An intricate jigsaw listening task, a map reading exercise, a discussion class based on recordings of casual conversations, simulated interviews in which students were required to provide personal information, and a comprehension class based on radio advertisements and magazine pictures were among the activities. The lack of communicative patterns of interaction was found in this classroom investigation.

Chen (2015) performed a study to see how practicing CLT in a mixed English discussion class affected the students. The following questions were used to see if L1 is essential in CLT classes and if its use helps learners improve their learning attitudes: What are the implications of using CLT in a mixed English conversion class? Is it OK to utilize L1 in a CLT classroom? Is it true that once the teaching techniques were changed, students' learning attitudes improved and they became more active learners?

The findings revealed that learners were comfortable with the use of CLT in the classroom; it was also demonstrated that using the mother tongue may lessen learners' anxiety in the CLT classroom. In fact, after modifying teaching techniques in the CLT classroom to include the use of L1, visual aids such as images, short films, and role acting, students displayed more positive learning attitudes and were active learners.

Bruner, Sinwongsuwat, and Radic-Bojanic (2015) conducted research at two Thai universities to see how CLT aided in the development of communicative competence. The goal of this research is to discover viable classroom methods for increasing the spoken English proficiency of Thailand's university low-proficiency students during a scholar year per university.

Classes in CLT were based on the use of meaningful communicative contexts that 
encouraged students to use English to convey their opinions in actual and real communication. Feedback was critical in helping students improve their speaking skill, and errors were allowed to exist as long as they did not start interfering with the meaning of the real message.

Both universities used materials to promote communication through CLT, collaborative activities were emphasized, and both groups gave it their all. However, because of the disparities in English levels, it was sometimes difficult to group students; one possible solution was to give students a placement test so that they could be grouped homogeneously later. Another issue with large groups was that it was difficult for teachers to keep track of their pupils' progress in communicative exercises. Students from one university were found to have more group work accustomed activities than students from the other university, indicating that cooperative activities should be encouraged more. Finally, both scripted and non-scripted dialogues occurred in both groups of students, with the latter being the more productive because it allowed students to express themselves freely. The findings of this study clearly show that authentic language contexts enable students to put all of the principles they've learned in class into practice; additionally, attempting to use English on their own will undoubtedly be an example of authentic language application they'll use when performing as professionals.

Muslem, Mustafa, Usman, and Rahman (2017) conducted a study using video clips to see if students' speaking abilities improved. Students were given a pre-test and a post-test for this study. The pupils were young learners who worked in small groups and on their own. After evaluating and comparing the findings of the pre- and post-tests, the authors came to the conclusion that the video clips helped students improve their speaking abilities in group work more than they helped students improve their speaking skills individually. Based on these findings, the authors recommend incorporating video clips into small group exercises using strategies like slowing down films and repeating key portions of the movie.

\section{Conclusion}

The instructor offered communicative activities to the students to aid in the adoption of CLT in the teaching of speaking. The instructor filled out the classroom activities with roleplaying exercises, finding/collecting information that conditioned the classroom in specific scenarios, such as interviewing their friends or determining the problem that other students may have expressed, and then providing counsel. The teacher asked the students to debate specific topics that were or had just been published in the news, newspaper, or magazine during another meeting. Furthermore, the instructor attempted to give a variety of learning materials, such as a textbook or to the tudents. The teacher would occasionally play audio materials, brief films 
or film footage, and discussion programs.

\section{REFRENCES}

Abdul Aziz, Azlina. 2019. “The Impact of the Implementation of CLT On Students' Speaking Skills" International Journal of Scientific and Research Publications (IJSRP) Volume 9, Issue 4. Bangi: ijsrp.

Abe, E. (2013). Communicative language teaching in Japan: Current practices and future prospects: Investigating students' experiences of current communicative approaches to English language teaching in schools in Japan. English Today, 29(2), 46-53.

Anggraini. 2018. Improving Students' Speaking Skill Through CLT An Action Research, Wanastra Vol X No.1. Bogor: ejournalbsi.

Bruner, D. A., Sinwongsuwat, K., \& Radic-Bojanic, B. (2015). EFL Oral Communication Teaching Practices: A Close Look at University Teachers and A2 Students' Perspectives in Thailand and a Critical Eye from Serbia. English Language Teaching, 8(1), 11-20.

Chen, W. (2015). A case study of action research on communicative language teaching. Journal $\begin{array}{llll}\text { of Interdisciplinary } & \text { Mathematics, } & \text { 18(6), }\end{array}$ https://doi.org/10.1080/09720502.2015.1108075.

Colker, L.J. (2007). Hand-on Learning. Washington, DC: National Association for the Education of Young Children.

Jeyasala, V. R. (2014). A prelude to practice: Interactive activities for effective communication in English. Alternative pedagogies in the English language \& communication classroom, 164-170.

McGrath, I. (2013). Teaching materials and the roles of EFL / ESL teacher: Practice and theory. New York: Bloomsbury Academic.

Moss, D., \& Ross-Feldman, L. (2003). Second language acquisition in adults: From research to practice. Retrieved from http://www.cal.org/CAELA/esl_resources/digests/SLA.html

Muslem, A., Mustafa, F., \& Rahman, A. (2017). The application of video clips with small group and individual activities to improve young learners' speaking performance. Teaching English with Technology, 17, 25-37.

Nunan, D. (1987). Communicative Language Teaching: Making it work. ELT Journal, 38(2), 136-145. https://doi.org/10.1093/elt/41.2.136 Peacock, M. (1997) The effect of authentic materials on the motivation of EFL learners. ELT Journal, 51(2), 144-156. https://doi.org/10.1093/elt/51.2.144.

Richards, J. C. (2006). Communicative language teaching today. SEAMEO Regional Language Centre. Richards, J. C., \& Rodgers, T. S. (2014). Approaches and methods in language teaching. Cambridge: Cambridge University Press.

Salaberry, R. (2001). The use of Technology for Second Language Learning and Teaching: A 
Retrospective. Modern Language Journal, 85(1), 39-56. https://doi.org/10.1111/00267902.00096.

Ulfah, Rosalina., Apriliaswati, Rahayu., Ar, Zainal. 2019. The implementation of communicative language teaching approach in teaching speaking. Pontianak: eprintsums.unsyiah.

Vanessa Toro, G. C.-M.-T. (t.thn.). The Use of the Communicative Language Teaching Approach to. English Language Teaching; Vol. 12, No. 1; 2019.

Wahyudi, Endri. 2017. The Use of Communicative Language Teaching (CLT) in Speaking Class. Salatiga: perpus iain salatiga.

Wana Putri, Nandita., Sukirlan, Muhammad., Sudirman. 2018. The Effect of Using CLT Improve Speaking. Lampung: media neliti

Wahyuningsi, Sri. 2019. Using Communicative Language Teaching to Improve Students' Ability. Makasar: digilibadmin unismuh.

Yasin, Burhanuddin., A, Zulfadli., Raudhatul Jannah, Aziz. 2021.Communicative Language Teaching (CLT) for Teaching Speaking. Banda aceh: jurnal. 